\title{
Viewpoints
}

\section{COVID-19 crisis in Nepal: A case of systems and governance failure in a low-income country}

\author{
Biplov Adhikari ${ }^{1}$,, Amrit Devkota $^{2}$ ㅇ, Shyam Sundar Budhathoki ${ }^{3}$, Richard Pinder ${ }^{3}$, Lila Bahadur Basnet ${ }^{4}$ \\ 1 Department of Internal Medicine, MedStar Union Memorial Hospital, Baltimore, United States of America, ${ }^{2}$ BP Koirala Institute of Health Sciences, \\ Dharan, Nepal, ${ }^{3}$ School of Public Health, Imperial College London, London, United Kingdom, ${ }^{4}$ Department of Health Services, Ministry of Health and \\ Population, Kathmandu, Nepal \\ Keywords: nepal, covid-19, politics, festivals, crisis \\ https://doi.org/10.52872/001c.27683
}

\section{Journal of Global Health Economics and Policy}

Vol. 1, 2021

\section{Early May 2021:}

A 38-year-old SARS-COV-2 positive man with mild symptoms was isolating at home. After several days, he became short of breath with pulse oximetry dropping to $88 \%$ on room air. With friends and families frantically calling all nearby hospitals for hours, a hospital bed was finally found. Upon admission, he received supplemental oxygen along with the available medicines. Two days after his admission the hospital ran out of medical oxygen. It was up to the family to find medical oxygen. Even after a full day's search for oxygen by all friends and family, not a single cylinder was found. A day later, gasping, he took his last breath. This is a common occurrence in Nepal during the second wave of the COVID-19 pandemic.

Only two months prior, Nepal had reported zero deaths on $10^{\text {th }}$ March 2021, there were 337 new cases diagnosed. Nepalese believed they were now moving towards the end of the pandemic. But, the scientific omens were suggesting otherwise. Across the border in India, a sharp rise in new cases was reported and deaths were soaring. ${ }^{2}$ Politicians on either side of the border were breaking the very regulations they had implemented to curb the spread of the virus, as they organised rallies and attended public events. By $14^{\text {th }}$ May 2021, there were 8520 new cases and 203 new deaths. ${ }^{1}$

Nepal has a notorious history of incompetency during times of crises. During the Earthquake in 2015, that cost the lives of more than 8000 people, the government of Nepal was widely criticized for being unable to even manage the aid that came in. The government had frenzied, unable to tend to the people in a particular location. And the COVID-19 pandemic, a calamitous infectious wrath that engrossed the whole nation only showed, again, how ill equipped the country was.

Nepal, a low-income country with highly constrained health resources, faces a scarcity of medical supplies including hospital beds, ventilators, oxygen, essential medicines, personal protective equipment, test kits, and vaccines against COVID-19. There is also a scarcity of trained medical professionals. As of $18^{\text {th }}$ May $2021,1.86 \%$ of the eligible population have been fully vaccinated against COVID-19. ${ }^{3}$ The health system has been unable to cope with the increasing number of patients and is at imminent risk of collapse.

\section{FACTORS LEADING TO THE CURRENT SITUATION IN NEPAL}

The government of Nepal fell behind in preparing for the second wave of the pandemic. During the first wave, COVID-19 pandemic was completely new to the entire world. Developing countries like Nepal did not take necessary precautionary measures to prevent the rapid and rampant spread of COVID-19. As a result, Nepal faced exponential COVID-19 cases, acute shortages of health delivery services, and health care workers. Lessons learned from the first wave have gone unheeded. Instead, the government and the ruling party allowed and led mass gatherings including rallies and inauguration ceremonies, when mass gatherings were not advised at all. Political figures continue to indulge in inter-and intra-party power struggles. Containing the pandemic was not sufficiently prioritised. Gatherings, in the form of festivals and marriages, have made the situation worse as the virus rampages through communities. Notable political events and festivals dates have been plotted along the line graph in Figure 1, showing daily and cumulative number of cases in Kathmandu valley where the national capital is located.

\section{THE TUMULTUOUS POLITICAL SCENARIO}

Nepal has a history of political instability. But, over the last three years Nepal has enjoyed a more stable government. This was until recently when a series of political fall-outs in the governing party returned the country to instability. The incumbent prime minister dissolved the parliament in December 2020. Thereafter, began a series of events demonstrating the splintering and in-fighting of the ruling Nepal Communist Party.

Mass partisan gatherings were convened in a show of power by different factions: people flocked to the events in droves travelling long distances. Social distancing, face coverings, masks, hand hygiene, and the fear of contracting the disease were largely disregarded as the country's political turmoil deepened. Attendees were provided with free meals and transportation. Revolution was brewing in the air. But there was a bigger threat - the novel coronavirus and its emerging variants, invisible to the eye ready to make its return. And when it did, nothing else mattered. Breathing be- 


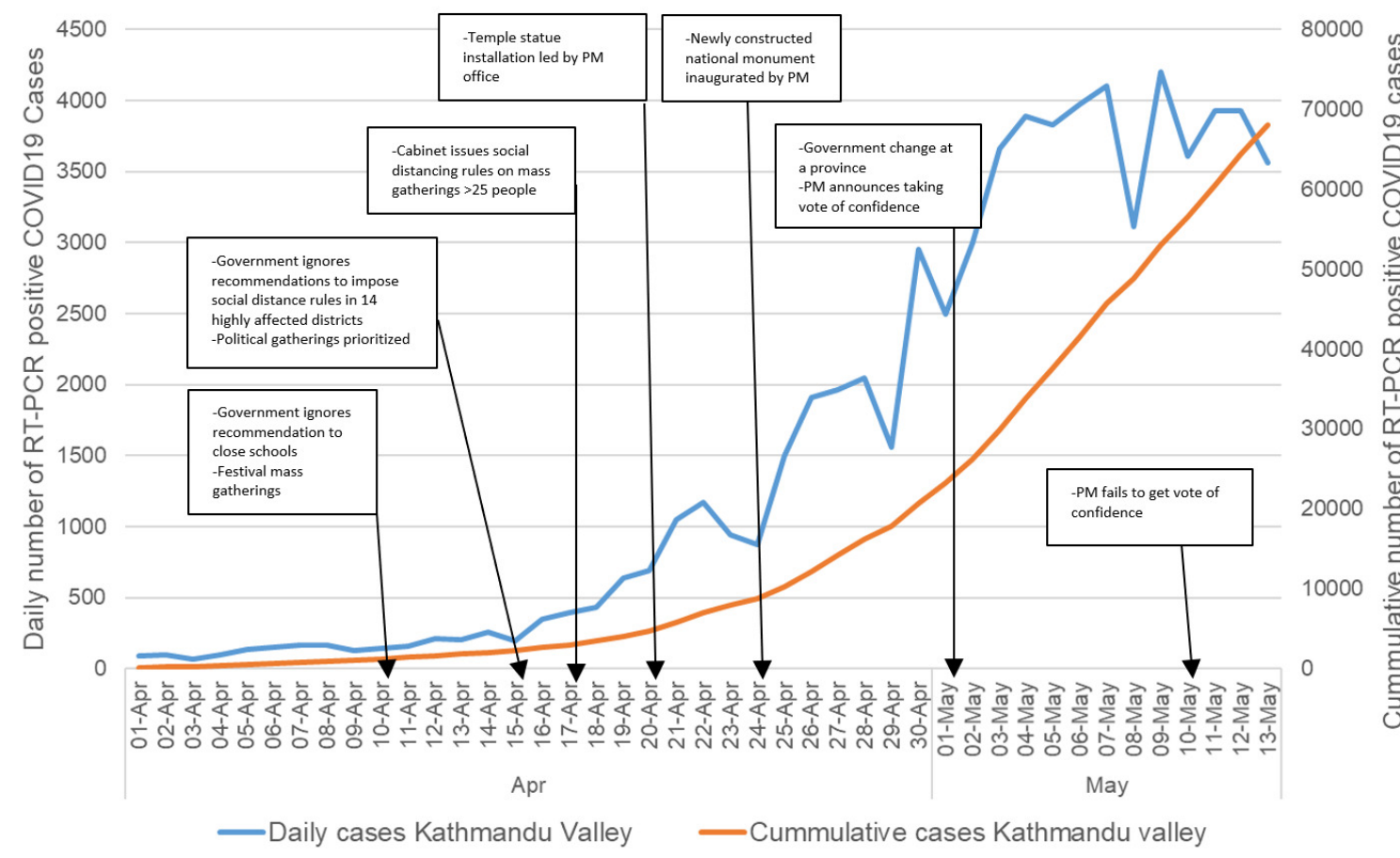

Figure 1. Daily and cumulative number of RT-PCR positive COVID-19 cases marked with key political social events

came a struggle. Hospitals became a distant hope.

While the members of parliament and their families received their second doses of vaccine, the elderly (>65-yearolds) became less and less likely to receive theirs as vaccine shortages ensued.

Despite the obvious calamity, the prime minister without scientific evidence, reassured the international community that the pandemic situation in Nepal was "under-control".4 On $22^{\text {nd }}$ May 2021, the president dissolved the parliament and called for elections. The gathering of people for elections will further escalate the crisis. ${ }^{5}$

\section{INAUGURATIONS}

The inauguration of buildings and other infrastructure in Nepal have been an important way for the government to showcase investment and social progress. While the government had imposed measures to prevent large gatherings and appealed to the general public to maintain social distancing and stay indoors, the prime minister himself and other cabinet ministers have traversed the country to inaugurate buildings and lay the foundation stones of future projects. ${ }^{6}$ These huge programmes have been attended by crowds numbering in the hundreds, and with minimal precautions.

The prime minister inaugurated the Dharahara (a national monument) on $24^{\text {th }}$ April $2021 .^{7}$ Despite the growing number of COVID-19 cases and warnings, the prime minister proceeded with the inauguration. The police could only observe. The regulations against mass gathering were disregarded each time.

\section{FESTIVALS (JATRAS)}

The situation leading to this health crisis has also been fueled by large congregations that came together either in the name of religion or in other cultural events.

In the spring, the Kathmandu valley (comprising Kathmandu, Bhaktapur, and Lalitpur districts) celebrates festivals termed 'Jatras'. Ethnic groups have been very vocal about their rights to practise their festivals. In 2020, a fight broke off between the local ethnic groups and police as the authorities sought to prevent them gathering en-masse. ${ }^{8}$ But this year many Jatras were allowed. These mass gatherings appear to have acted as super-spreader events: as suggested by the sudden spikes in the number of cases and mortality immediately following these festivals. Figure 1 depicts the effect of festivals in raising the number of COVID-19 cases in Kathmandu valley. ${ }^{9}$

The Nepalese ex-monarch and his family contracted COVID-19 around the time they attended the Maha Kumbh Mela in India. Over 100,000 Nepalese are estimated to have attended the Kumbh Mela and are believed to have imported the disease to Nepal. ${ }^{10}$ Despite the knowledge that Nepal would suffer a similar fate to India, the festivals carried on. The consequences were inevitable.

Apart from religious festivals, the spring in Nepal also heralds the season of marriages. Marriages in the Hindu culture are elaborate events attended by extended lists of guests. These celebrations are also believed to have turned into spreader events in both India and Nepal. ${ }^{11}$ Only recently have tighter measures been implemented to reduce the number of attendees in marriages. 


\section{CONCLUSION}

Understanding the Nepal's socio-economic status and health implications of COVID-19 pandemic, political parties must put aside their political activism and unite to combat the pandemic. Furthermore, political parties can also mobilize their youth wings to create awareness regarding the COVID-19 pandemic. Local public representatives can play a pivotal role in sanctioning and effective utilization of limited health resources. In addition, government should urgently seek for international aids on essential resources like vaccines, oxygen supplies, medicines, etc. Similarly, proper coordination is necessary among local governments, central government, and private stakeholders in establishing a unified agenda on prohibition of mass gatherings in terms of rallies, festivals; coordinated utilisation of limited health resources and manpower is of utmost importance to keep the pandemic under control in Nepal.

\section{ACKNOWLEDGEMENTS}

None.

\section{ETHICS APPROVAL}

None sought.

\section{FUNDING}

None.

\section{AUTHOR CONTRIBUTIONS}

SSB, BA, and AD conceptualised the article. AD and BA prepared the first draft. SSB, LBB and RJP edited and added to the subsequent drafts. All authors agreed together on the final draft.

\section{COMPETING INTERESTS}

The authors completed the ICMJE Unified Competing Interest form at (available upon request from the corresponding author), and declare no conflicts of interest.

\section{CORRESPONDENCE}

Biplov Adhikari, biplov.adhikari.91@gmail.com Shyam Sundar Budhathoki, ss.budhathoki@gmail.com Richard Pinder, richard.pinder@imperial.ac.uk Lila Bahadur Basnet, drlbbasnet@gmail.com Amrit Devkota, amritdevbpkihs@gmail.com

Submitted: July 26, 2021 CET, Accepted: August 20, 2021 CET

This is an open-access article distributed under the terms of the Creative Commons Attribution 4.0 International License (CCBY-4.0). View this license's legal deed at http://creativecommons.org/licenses/by/4.0 and legal code at http://creativecommons.org/licenses/by/4.0/legalcode for more information. 


\section{REFERENCES}

1. CoVid19-Dashboard. Published May 16, 2021. Accessed June 5, 2021. https://covid19.mohp.gov.np/.

2. India COVID: $28,799,401$ Cases and 346,597 Deaths. Worldometer. Accessed June 5, 2021. http s://www.worldometers.info/coronavirus/country/indi a/.

3. Nepal - COVID-19 Overview - Johns Hopkins. Johns Hopkins Coronavirus Resource Center. Accessed June 5, 2021. https://coronavirus.jhu.edu/region/nepal.

4. Nepal PM: Covid situation is under control. CNN Video. Accessed May 16, 2021. https://edition.cnn.co m/videos/world/2021/05/08/nepal-covid-coronavirusprime-minister-sharma-oli.cnn.

5. Nepal president dissolves parliament, new election in November. Reuters. Accessed May 24, 2021. http s://www.reuters.com/world/asia-pacific/nepal-preside nt-dissolves-parliament-new-election-november-202 1-05-22/.

6. Brushing pandemic aside, Nepal PM embraces inauguration spree to create fake impressions. OnlineKhabar English News. Accessed May 16, 2021. https://english.onlinekhabar.com/brushing-pandemi c-aside-nepal-pm-embraces-inauguration-spree-to-c reate-fake-impressions.html.
7. Prime Minister Oli inaugurates historical Dharahara. The Himalayan Times. Accessed May 16, 2021. https://thehimalayantimes.com/kathmandu/pri me-minister-oli-set-to-inaugurate-historical-dharah ara.

8. Locals and police clash in Pulchowk over pulling of Rato Machhindranath chariot. Accessed May 16, 2021. https://kathmandupost.com/lalitpur/2020/09/03/local s-and-police-clash-in-pulchowk-over-pulling-of-rat o-machhindranath-chariot.

9. CoVid19-Dashboard. Published May 16, 2021. Accessed June 5, 2021. https://covid19.mohp.gov.np/.

10. After Kumbh Mela visit, Nepal's former King Gyanendra tests COVID-19 positive. The Hindu. Accessed May 16, 2021. https://www.thehindu.com/n ews/international/after-kumbh-mela-visit-nepals-for mer-king-gyanendra-tests-covid-19-positive/article3 4366544.ece.

11. Superspreader events like weddings behind new Covid surge: Govt panel. Hindustan Times. Accessed May 16, 2021. https://www.hindustantimes.com/indi a-news/superspreader-events-like-weddings-behindnew-covid-surge-govt-panel-101616177606318.html. 